FACTA UNIVERSITATIS

Series: Economics and Organization Vol. 17, No 4, 2020, pp. 299 - 316

https://doi.org/10.22190/FUEO200801022A

Original Scientific Paper

\title{
OIL PRICE SHOCKS AND MACROECONOMIC PERFORMANCE OF THE NIGERIAN ECONOMY: A STRUCTURAL VAR APPROACH
}

\author{
UDC 622.323:338.5]:330.101.541(669)
}

\section{Raymond Osi Alenoghena}

Department of Economics, University of Lagos, Akoka, Lagos, Nigeria

\begin{abstract}
This study examines the effect of oil price shocks on the macroeconomic performance of the Nigerian economy covering the period from 1980 to 2018. The effect of oil price shocks is investigated on macroeconomic variables like output growth, inflation, interest rate, exchange rate and industrial production index using the structural vector autoregression (SVAR) approach. The results of the investigation reveal that oil price shocks have significantly and negatively affected economic growth and industrial output. Furthermore, while the results show that oil price shocks have a significant positive effect on inflation, the effect is also positive on interest rate and exchange rate, but it is not significant. The results of impulse response function show a negative effect on output growth, it is positive on inflation, but mild and indeterminate on industrial production, interest rate and exchange rate. Based on findings in this study, the Renaissance theory and the Dutch Disease theories of economic growth apply to the Nigerian economy. The policy recommendations include the isolation of the country's real sector from the vagaries of oil price volatility and the pursue of economic diversification to reduce the over-dependence on oil.
\end{abstract}

Key words: Oil price; Economic Growth, Inflation; Exchange Rate; Industrial Production; SVAR

JEL Classification: C32, E30, F41, Q43

\section{INTRODUCTION}

Oil has served as the most potent source of energy supply for the industrial development of nations across the world since the 1950s. The dependence on oil for industrial performance has been marked with uncertainty as a result of several global events that have affected the

Received August 01, 2020 / Revised October 27, 2020 / Accepted October 29, 2020

Corresponding author: Raymond Osi Alenoghena

Department of Economics, University of Lagos, Akoka, Lagos, Nigeria

E-mail: raymondalen2002@gmail.com

(C) 2020 by University of Niš, Serbia | Creative Commons Licence: CC BY-NC-ND 
selling price of oil in the world market. For instance, there was the Arab-Israeli War of 1973, the Gulf War of 1990-1991 and the Asian financial crisis in 1987. Another global financial disruption was witnessed during the terrorist attack at the World Trade Center in New York on September $11^{\text {th }}$, 2001. Equally remarkable was the global financial crisis of 2007-2008 that was caused by subprime mortgages. Perhaps of more significance is the on-going global crisis with very severe financial implications caused by the novel pandemic flu called the coronavirus. As expected, in all of these crises, industrial production was affected, and energy consumption disrupted, leading to a change in the world price of oil. With the advancement of nations and the accelerated growth in several developing countries of the world, the world market price of crude oil maintained an upward trend since the early 70s (Ahmed \& Wadud, 2011). The global price of oil attained a peak of US $\$ 145$ per barrel on July $3^{\text {rd }}, 2008$, during the global financial crisis. However, in recent times, the lowest price of oil has been US $\$ 12.34$ per barrel on April $28^{\text {th }}, 2020$, based on the world-wide sludge in economic activity occasioned by the coronavirus pandemic. A lot of uncertainty has been associated with the universal production of oil and its pricing as a result of the close link with the world-wide economic and financial events (Iwayemi \& Fowowe, 2011).

Despite innovations around the world on alternative sources of energy, crude oil still represents the primary source of power in the world today (Nazir \& Hameed, 2015). The role of energy in different sectors of a modern economy cannot be over-emphasized. For instance, oil is needed to produce electricity, operate machines for production and transportation: Oil products are used as industrial raw material, in telecommunications, building and construction as well as durable household consumables. It means that oil products are used in all the economies around the world, even where such countries are not endowed with crude oil resources. Therefore, most economies around the world are affected by changes in the price of oil in the world market. Whenever there is a serious disruption in the supply of oil to the world market, economic entities become skeptical about the future. There is a temporary fall in consumers' spending on investment goods, household appliances, housing, cars, and so on (Hamilton, 2003).

The existing literature on energy economics has been replete with the debate on the effect of change in world oil price on the level of economic activity. The change in oil price has been found to affect most macroeconomic variables of economies around the world. While oil production would benefit the producing country through revenue earnings from oil sales, it may also have long term effect on the structure and composition of the country's industrial and total output (Okonkwo \& Mojekwu, 2018). Changes in the price of oil may also affect inflation and interest rate (Sek et al., 2015). Since oil sale is denominated in US Dollar, the change in the universal price of oil has significantly affected the exchange rate of the oilproducing countries as well as the oil-importing countries (Volkov \& Yuhn, 2016).

The Nigerian situation is unique as the country exports crude oil and imports refined oil products from the advanced countries of the world. Since the production of oil in the 50 s, the country grew to systematically neglect the other productive sectors of the economy (Udoka \& Nkamare, 2014). With the focus on oil production and export, the country has become a mono-product economy. The returns from oil exploration made the government relegate other sources of revenue, including taxation. A country that was reputed for producing and exporting groundnut, rubber cocoa, palm oil, has relegated the production of other export items over the years to concentrate on crude oil. Between 1981 and 2018, the revenue from crude oil export in Nigeria has accounted for over $70 \%$ of the total government collected revenue for the period (CBN, 2018). All efforts to develop the 
manufacturing sector have failed as the existing few functional manufacturing concerns are almost entirely dependent on the importation of raw material inputs to function. Most states of the country are notorious for their low IGR collections and are condemned therefore to wait for federal allocation and sharing of oil revenue from crude oil export. The country's situation is so bad that the cost of running government, the funding of projects and the monthly remunerations for civil servants all come from federal government oil earnings.

The country's oil export is coordinated by the Nigerian National Petroleum Corporation (NNPC), the government behemoth that has been saddled with corruption over the years. Inflation in Nigeria has been double-digit for many decades, and some authors believe that a significant cause is oil price volatility. Omojolaibi (2013) opines that oil revenue has affected inflation in Nigeria through money supply. Also, some authors have argued that with oil production in Nigeria, the structure of production changes, and consumers have acquired the taste for foreign goods (Aydina, \& Acarb, 2011). Therefore, as imports are encouraged, and exports are discouraged, the terms of trade could turn against the country. The emerging trend would depreciate the country's domestic currency against the Dollar over the years.

As new trends from the effect of oil price changes on the economy emerge daily, further studies on the impact of oil price shocks on macroeconomic variables in developing countries like Nigeria have remained viable. This study is fashioned to examine the effect of oil price shocks on macroeconomic variables like output growth, inflation, interest rate, exchange rate and industrial production in Nigeria. Nigeria is a classic example of an emerging developing country that exports crude oil and imports processed oil products.

The remaining part of this study is organized as follows. Section 2 briefly reviews the relevant literature concerning the effect of oil price shocks on the economy. Section 3 is concerned with the applied literature on the subject matter of the study. Section 4 discusses the data source, variable definitions and econometric methodology. Section 5 examines the empirical analysis and results. Finally, Section 6 outlines the conclusions and policy implications of the paper.

\section{LITERATURE REVIEW}

Many studies have investigated the effect of oil price shocks on macroeconomic variables around the world. Perhaps most outstanding is the effect of oil prices on economic growth, inflation, exchange rate and industrial output. The other studies on this subject matter may include the effect of oil activities on a country's sovereign risks and perhaps investors' sentiments and uncertainties. On the relationship with economic growth, there are three categories of outcomes in the studies. The first set of studies argues that oil price shocks have positively impacted on economic growth. For instance, Omojolaibi (2013) examined the effect of crude oil price changes on economic activity in Nigeria between 1985 and 2014. He concluded that oil price changes positively affected economic growth. In the same year, Igberaese (2013) studied the Nigerian economy and drew a similar conclusion. Ani et al. (2014) examined the causal relationship between four macroeconomic variables: real GDP, exchange rate, inflation rate and interest rate in Nigeria. They found that a positive but insignificant relationship existed between oil price and GDP. In the same vein, Yukata (2015) in the study of more advanced countries like US, EU and Japan, argues that oil price increase benefits the more advanced economies. In a related study, Ifeanyi \& Ayenajeh 
(2016) utilizing secondary data from 1980 to 2014, concluded that crude oil price volatility positively and significantly related to economic growth in Nigeria.

The second set of studies on this subject matter argues that oil price shocks have negatively impacted on economic growth. Bekhet and Yusop (2009), in their study of oil prices and macroeconomic variables in Malaysia, concluded that oil prices negatively affected GDP growth and energy consumption. Tang et al. (2010), in their study of China from 1998 to 2008, found that an increase in oil-price negatively affected investment and output. Iwayemi \& Fowowe (2011), in their study of Nigeria 1985 to 2007, concluded that positive oil shocks did not cause GDP but negative oil shocks significantly caused output and the real exchange rate. Similarly, Alley et al. (2014) utilized GMM model to investigate the effect of oil price shocks on economic activities in Nigeria and concluded that oil price uncertainty reduces the level of economic activity in a small open oil-producing economy like Nigeria. Also, Nazir \& Hameed (2015), investigated oil prices and GDP in Pakistan using data covering from 1972 to 2011 and concluded that oil prices affected real GDP negatively in the long run. Kiliçarslan \& Dumrul (2017) conducted a similar study in Turkey and deployed SVAR analysis for the period from 2005Q1 to 2017Q2. The evidence confirmed that a rise in the price of crude oil elicited a decline in economic growth and increased crude oil prices, inflation and real exchange rate. The final set of studies on the relationship between oil price shocks and economic growth posit that the variables have no effect on each other. This is the position of Muhammad \& Ghulam (2017) in their study of Pakistan.

Another set of studies investigate the effect of oil price changes on the consumer price index or inflation. Oil price changes will likely affect consumer prices since crude oil products constitute a direct input for many consumer goods (Sek et al., 2015). One of the earliest studies in this relationship was conducted in India by Bhattacharya \& Bhattacharya (2001) using monthly data running from April 1994 to December 2000. Utilizing VAR models and impulse response function, they found that 20 percentage point shock in oil prices lead to a 1.3 percentage point increase in inflation in other commodities. Similarly, Dawson (2007) studied the OECD countries and found that a $1 \%$ increase in the oil price elicited a $2.9 \%$ depreciation in the real exchange rate. Also, Bermingham (2008) in a study of Ireland from 1996 to 2008 deployed Engle-Granger and ARDL approaches and found that the rising price of oil significantly affected inflation. Castillo et al. (2010) examined the case of United States of America. They isolated the average levels of the oil price and inflation to form three sub-samples, covering the periods 1970-1983, 1984-2002 and 20022008. They observed that an increase in oil price volatility triggers a higher level of inflation level. Ogundipe et al. (2014) used annual data spanning 1970 to 2011 to investigate the effects of oil price, exchange rate volatility, external reserves and interest rate in Nigeria. Using Johansen Co-integration and VECM techniques, they found that a proportionate change in oil price elicited a more than proportionate response from exchange rate volatility. Jiranyakul (2016) investigated Thailand data from 1993 to 2015 using the Johansen cointegration test and Granger causality tests. The study concluded that an oil price shock causes inflation index to rise while oil price uncertainty has no effect on the increase in inflation. Bala \& Chin (2018) investigated the asymmetric effect of oil price shocks on inflation in small oil exporting economies like Nigeria, Libya, Algeria and Angola. Utilising the NARDL dynamic panels, they observed that both the positive and negative oil price changes affected the level of inflation. While examining the relationship between inflation, oil prices and exchange rate, Mukhtarov et al. (2019) studied Azerbaijan and utilized VECM technique on data covering the period 1995 to 2017 . They found that 
a $1 \%$ increase in oil prices and exchange rate causes inflation to increase by $0.58 \%$ and $1.81 \%$, respectively.

The Market transactions concerning the purchase and sale of oil products and services are usually handled in US\$. Therefore, any change in the price of oil affects the exchange rate of the countries that may be involved in oil transactions. For instance, an increase in the universal price of oil causes depreciation in the dollar of the oil importing countries and an appreciation of the country that exports the oil. Several studies have been conducted on the relationship between oil price changes and the exchange rate of the countries that may be buying or selling oil products and services. Olomola \& Adejumo (2006) deployed VAR in the study of the effects of oil price shocks on output, money supply, real exchange rate and inflation in Nigeria. They found that oil price shocks have a significant effect on the real exchange rate in the long run. Similarly, Dawson (2007) studied the Nordic and OECD countries using multivariate econometric analysis and confirmed that oil price fluctuations significantly affected the relative value of currencies of the countries. More specifically, a $1 \%$ increase in the price of oil causes $2.9 \%$ depreciation in the real exchange rate in those countries. On the contrary, Huang \& Guo (2007) in the study of China, conclude that real oil price shocks would only stimulate a minor appreciation of the real exchange rate in the long-term because of China's lean dependence on oil that is imported. Narayan et al. (2008) investigated the oil price-exchange rate nexus for Fiji Islands, adopting daily data over the period 2000 to 2006. Utilizing GARCH and EGARCH models, they observed that a rise in the price of oil induced an appreciation of the local currency (Fijian dollar) in relation to the US\$. Coleman et al. (2010) examined the nonlinear relation between real exchange rate and real oil prices in 13 African countries using quarterly sample that span 1970Q12004Q4. They found that real oil prices and real exchange rates are co-integrated and that the price of oil plays an important role in real exchange rate determination. Studying the oil price-exchange rate linkage in Nigeria, Adeniyi et al. (2012) utilized monthly data covering the period 2009M1 to 2010M9. Deploying GARCH and EGARCH techniques, they affirmed that the rise in oil price stimulated an increase in the exchange rate in Nigeria over the period of study. Tiwari et al. (2013) utilized a wavelet transform framework on monthly data observations spanning the period 1986M2-2009M3. They confirmed that changes in oil prices have a strong influence on the real effective exchange rate fluctuations in both the short run and large time horizons.

Still on oil price shocks and currency exchange rates, Sibanda \& Mlambo (2014), empirically examined the impact of oil prices on exchange rate in South Africa using monthly data covering the period between 1994 and 2012. They found that an increase in oil price stimulated a depreciation of the rand exchange rate. Oil price significantly impacted on the nominal exchange rate in South Africa. The effect of changes in price of oil on exchange rates in Nigeria was examined by Osuji (2015) using monthly data covering the period 2008M1 to 2014M12. Utilizing OLS and VECM, he observed that oil price movements have a significant causal effect on Exchange rate and the country's foreign reserves. Volkov \& Yuhn (2016) investigated the relationship between oil price shocks and the volatility of exchange rate comparing the emerging markets with the developed and advanced markets. Using VECM and GARCH over the period 1998 - 12, they observed that oil price shock is significant in determining exchange rate in emerging markets (Russia, Brazil, and Mexico), but weak in advanced markets (Norway and Canada). In an effort to investigate the dynamics of oil price volatility between the US $\$ /$ Euro exchange rate and the general oil market, Jawadi et al. (2016) deployed intraday 
data in a GARCH volatility approach on a monthly data covering the period between 2014:9 to 2016:1. The analysis revealed that a negative relationship existed between oil returns and the US dollar/Euro rates, implying that an appreciation of the US\$ reduced the price of oil in the market. Also, there is a volatility spillover to the general oil market from the US exchange market through the intraday jumps. In a study of six oil-dependent economies over the periods 2000-2007 and 2010-2016, Mensah et al. (2017) used Johansen Co-integration test to explore the relationship between oil price and exchange rate. They confirmed the existence of a growing inverse relationship between oil price and exchange rate, especially in the post-crisis period. Finally, while examining the dynamic effects of the various types of oil price shocks on the real exchange rates of countries that are net importer and exporter, Ji et al. (2020) adopted monthly data spanning from 1974:2 to 2016:12 and deployed an SVAR model. The study results show that oil supply shocks produced greater depreciating effects on exchange rates for the oil exporting countries than the importing countries.

Some studies have examined the relationship between oil price shocks and industrial output. Most of the studies agree that oil price shocks have a negative effect on the industrial output of the economies (Ahmed \& Wadud, 2011; Awartani et al. 2019). Perhaps more recent studies have emerged on the effect of oil related activities on the sovereign risks of nations. For instance, in the study of the effect of oil volatility shocks on the sovereign risk of BRICs countries, Bouri et al. (2018) adopted monthly data from 2009:7 to $2017: 3$ and deployed a multivariate quantile regression. The findings underscored the presence of asymmetry between oil exporters and oil importers with the former being more sensitive to positive oil shocks while the latter showed more sensitivity to the negative oil shocks. While deploying daily data spanning from February $14^{\text {th }}, 2011$ to July $31^{\text {st }}, 2019$, Bouri (2019) examined the effect of oil jumps on the sovereign risk of some major world oil exporters. The results showed that the sovereign risk of the countries, though may not be affected by oil price jumps, were significantly impacted by oil volatility jumps indicating a contagion effect. While deploying a quantile-based approach in a study of oilexporting and importing MENA countries, Bouri et al. (2020) examined how levels of oil volatility and returns affect the sovereign risk of countries in settings that are static and time-varying. They found that the sovereign risk of the countries in the study had specific implications for the oil crash of 2014-2016. The shocks in oil volatility and prices predicted the sovereign risk of the countries with spreads that are time varying and the oil returns impacts across quantiles that were asymmetric. The impacts of disaggregated oil price shocks on investor sentiments and uncertainties for both the short-run and long-run asymmetries was analysed by Shahzad et al. (2019) using the data span of 1995:1 to 2015:12 in a NARDL framework. They conclude that while oil demand shocks affected uncertainties, the oil supply shocks impacted treasury rates. Investor sentiments are affected by both the oil demand and supply shocks.

The gaps in the existing literature on the Nigerian economy stem from the fact that the existing studies like Iwayemi \& Fowowe (2011), Omojolaibi (2013), Ogundipe et al., (2014) and Osuji (2015) on the Nigerian economy did not cover an extended period and utilized a limited number of variables. This study covers this lacuna by covering the period of oil price volatility in the world market (2015-2016) and utilizing six macroeconomic variables in the study. Also, studies of this nature which are conducted on a developing economy that produces and exports oil and imports the finished oil-based products are often very revealing at each stage because of the growing and dynamic nature of the global economy. 


\section{THEORETICAL FRAMEWORK}

Within the economic growth literature, there are several growth theories that attempt to establish the relationship between oil price volatility and the macroeconomy or some parts thereof. In what follows, this study tries to briefly highlight four (4) of such theories, namely the Linear/symmetric relationship theory of growth, the Asymmetry-in-effect theory of economic growth, the Renaissance growth theory, and the Dutch disease theory of economic growth. The Linear/Symmetric relationship theory of growth postulates that the fluctuations in a country's total output (GDP) are often occasioned by the volatility in oil prices. Based on the theory, an inverse relationship exists between oil price volatility and the GDP growth in the economy. The pioneering work on this theory was done by Hamilton (1983). As a follow-up, Hooker (1996) building on the work of Hamilton confirmed that a $10 \%$ increase in oil price was associated with a $0.6 \%$ drop in GDP growth. Also, a similar conclusion was reached by Laser (1987) and Rotemberg \& Woodford (1996). On the other hand, Lee et al. (1995) observed that such a sudden and unexpected increase in the price of oil, induced a significant and asymmetric effect on total output and other macroeconomic variables including personal incomes and other forms of earnings.

The Asymmetry-in-effect theory of economic growth proposes that a decline in oil prices is associated with no significant effect on the economic activities in the US and some OECD countries (Mork, 1989; Lee et al. 1995; Ferderer, 1996). For instance, Mork (1989) expanded the work of Hamilton (1983) by investigating the asymmetric response of oil price volatility by disintegrating oil price volatility into real price increases and decreases. The findings show that oil price drop is significantly different and perhaps zero. The results of Mork (1989) are reinforced in the study of Lee et al. (1995) when they examined the asymmetry-in effects during the period before and after 1985. Lee et al. (1995) were able to resolve the issue of whether the asymmetric effect is dependent on the macroeconomic variable or not. As a follow-up, Ferderer (1996) sought to explain the asymmetric relationship between oil price volatility and economic activity by introducing three possible activity channels: sectoral shocks, counter-inflationary monetary policy and uncertainty. Ferderer concluded that the asymmetric oil price-output relationship is partly explained by the responses found in asymmetric monetary policy.

The Renaissance growth theory is considered an extension/fall-out of the symmetric relationship theory of economic growth. The Renaissance growth theory attempts to examine the relative effect of oil price changes or oil price volatility on the level of economic activity of a country during a given time frame. Along this line, Lee (1998) concludes that oil price change and oil price volatility both affect economic growth negatively, but the effect of changes in oil prices wears out immediately after one year. Therefore, Lee (1998) confirmed that the long run appreciable effect on economic growth may be attributed to the volatility in oil prices rather than the changes in the oil price level.

The Dutch disease theory of economic growth posits that higher oil prices would generally alter the production structure of the oil-exporting country to ensure that it concentrates more on oil production and exploration while ignoring the growth of the other sectors of the economy. The accruing increased levels of oil revenues would make for the appreciation of the country's local currency and induce an increase in the country's taste for and import of consumer goods. Consequently, the tendency for increased import of consumer goods would reduce the competitiveness and discourage the local producers. Therefore, the Dutch disease theory contends that an increase in oil prices will not eventually benefit the economy of an oil exporting country (Corden \& Neary, 1982). 


\section{THE MODEL}

The dynamics of oil price can be modeled based on the theoretical postulations of Huang \& Gio (2007) and Ahmed \& Wadud (2011). Their postulation suggests that a stochastic process relates the oil price $\left(\mathrm{Op}_{t}\right)$ to the aggregate supply $\left(\mathrm{S}_{\mathrm{t}}\right)$ and aggregate demand $\left(D_{t}\right)$ activity of the economy at any point in time, hence:

$$
O P_{t}=O P_{t-1}+\varepsilon_{t}^{O P}
$$

Aggregate supply can be modeled as follows:

$$
S_{t}=S_{t-1}+\varepsilon_{t}^{S}
$$

Similarly, aggregate demand can also be modeled accordingly,

$$
D_{t}=D_{t-1}+\varepsilon_{t}^{D}
$$

However, the aggregate supply of output $\left(Y_{t}^{S}\right)$ may be determined by the process of random walk which leads to equilibrium and the price of oil may now be given as,

$$
Y_{t}^{S}=S_{t}+\beta_{1} O P_{t}=S_{t-1}+\varepsilon_{t}^{S}+\beta_{2} O P_{t}
$$

Where, $\beta_{1}$ and $\beta_{2}$ are the coefficients of the elasticity of inverse energy of output. Similarly, the process of aggregate demand for output may also be determined by its own process of random walk and exchange rate (e),

$$
Y_{t}^{D}=D_{t}+\psi_{1} e_{t}=D_{t-1}+\varepsilon_{t}^{D}+\psi_{2} e_{t}
$$

Where $\psi_{1}$ and $\psi_{2}$ are the coefficients of elasticity of demand for energy output. Equations (4) and (5) are similar to the LM and IS form of the aggregate supply and aggregate demand models in macroeconomics which depict the aggregate domestic supply and demand prices for the output of oil in relation to the exchange rate and other macroeconomic variables like inflation, exchange rate, interest rate and industrial output. Huang and Guo (2007) have been able to demonstrate why the real GDP is affected by the supply output and the shocks in oil prices; hence, the oil price shocks can potentially affect the real oil price in the long run. The model to be estimated is represented as follows

$G D P R_{t}=\alpha_{0}+\alpha_{1} O_{I L P_{t 1}}+\alpha_{2} I N F L_{t 2}+\alpha_{3} I N T R_{t 3}+\alpha_{4} E X R_{t 4}+\alpha_{5} I P I_{t 6}+\mu_{t}-6$

Where: $\alpha_{0}, \alpha_{1}, \alpha_{2}, \alpha_{3}, \alpha_{4}$ and $\alpha_{5}$ are the coefficients to be estimated and $\mu_{t}$ is the stochastic error term. Furthermore, GDPR represents Economic Growth; OIL is Oil Price; INFL is Inflation; INTR is Interest Rate; EXR is Exchange Rate and; IPI is Industrial Production Index.

\subsection{Data Sources}

The study uses SVAR model over the period 1981 to 2018, which provides 39 annual observations. The variables adopted include: crude oil price, economic growth, Inflation (Consumer Price), Interest rate, Exchange Rate and Industrial production index.

The source of data for this work is mainly secondary data from the World Development Indicators (World Bank). The data set for the variables on consumer prices and industrial production through the WDI source ends at 2018, at the time of writing this article. To standardize the variables, we use the natural logarithm for all variables. The full name, description and source of the data are presented in the table 1. 
Table 1 Data and Variable Description

\begin{tabular}{llll}
\hline Variable Full Name & Description & Source \\
\hline OILP & Brent Crude Oil Price & UK Brent Crude Oil in US\$ per barrel & UNCTAD \\
GDPR & Economic Growth & The annual growth rate (percentage) of GDP at market & WDI \\
& & prices: Estimated as $\left(\frac{Y_{t}-Y_{t-1}}{Y_{t-1}}\right) \%$ for each year & Consumer Prices at annual \% change \\
INFL & Inflation & Lending rate at which Banks meet the short and & WDI \\
INTR & Interest Rate & $\begin{array}{l}\text { medium-term financing needs of government and the } \\
\text { private sector. }\end{array}$ & Value added is the net output of Industrial sectors \\
IPI & Industrial Production & WDi \\
& Index & $\begin{array}{l}\text { after adding up all outputs and subtracting } \\
\text { intermediate inputs. }\end{array}$ & Price at which Nigeria local currency (Naira) \\
EXR & Exchange Rate & exchange for one unit of US\$ & WDI \\
\hline
\end{tabular}

\subsection{Analytical Framework}

In the classical state, a VAR framework has all the variables endogenous and comprised in the set $\mathrm{K}$ observations as follows,

$$
Y_{t}=\left(y_{1 t}, y_{2 t}, y_{3 t}, \ldots, y_{k t}\right)
$$

For $\mathrm{k}=1 \ldots \mathrm{p}$. Hence, the VAR (p)-process can be formally defined as:

$$
y_{t}=A_{1} y_{t-1}+A_{2} y_{t-2} \ldots+A_{p} y_{t-p}+\mu_{t}
$$

Where $A_{i}$ are $\left(\mathrm{K} \mathrm{X} \mathrm{K)}\right.$ coefficient matrices for $\mathrm{i}=1 \ldots \mathrm{p}$ and $\mu_{t}$ is $\mathrm{k}$-dimensioned with $\mathrm{E}\left(\mu_{t}\right)=0$ and time-invariant with positively defined covariance matrix $\mathrm{E}\left(\mu_{t} \mu_{t}^{T}\right)=\sum u$ (white noise). When given sufficient starting values, the VAR (p)-process is stable and generates stationary time series with reliable means, variances and covariance. A VAR (p) is a reduced form simultaneous equation model. The dynamics of the VAR indicators are obtained by a mechanical technique which is unrelated to economic theory. The Structural VAR technique was developed to account for the short-coming of VAR by imposing restrictions to make the technique more related to existing economic theory. SVAR model in its standard form can be defined as:

$$
A y_{t}=A_{1}^{*} y_{t-1}+A_{2}^{*} y_{t-2}+\cdots+A_{p}^{*} y_{t-p}+\beta \varepsilon_{t}
$$

We can resolve equation (9) for $y_{t}$ as follows:

$$
A y_{t}=A^{-1} A_{1}^{*} y_{t-1}+A^{-1} A_{2}^{*} y_{t-2}+\cdots+A^{-1} A_{p}^{*} y_{t-p}+A^{-1} \beta \varepsilon_{t}
$$

Where $A_{i}^{*}$ for $\mathrm{I}=1 \ldots \mathrm{p}$ represent the structural coefficients which in general form differ from the corresponding VAR form counterparts. The SVAR model is more adjusted to identify shocks through structural impulse response functions (IRF). The IRF demonstrates the dynamic responses of each variable to the present and future values of the other variables. The structural variance decompositions display the volume of information that each variable gives to the others in the autoregression as the variation in an endogenous variable is divided into component shocks of VAR and allocates the variance of forecast errors in a given variable to its own shocks and other variables. The SVAR model emphasizes 
the imposition of restrictions through the inversion of stationary Vector Autoregressive Representation (VAR).

$$
y_{i}=A_{1}^{-1}(L)+\varepsilon_{t}
$$

Where $y_{i}$ represents the vector of the variables which are to be included in the model and $A_{1}^{-1}(L)$ refers to the inverted coefficient matrix while $\varepsilon_{t}$ is the error term. To obtain the process of linear combinations which reflect past innovations in line with Wald compositions, we make $A_{1}^{-1}(L)=\Phi(L)$. Therefore,

$$
y_{t}=\Phi(L) \mu_{t}=\sum_{h=0}^{\infty} \Phi_{h} \mu_{t-h} \quad-\quad--
$$

To recover the unobservable relevant shocks $\left(\varepsilon_{t}\right)$ out of the observable reduced form innovations, a structural VAR representation is constituted through the imposition of a set of restrictions. Therefore, the Structural VAR form should be stipulated:

$$
A_{1} y_{1}=\sum_{i=1}^{p} A_{1}^{*} y_{t-1}+\beta \varepsilon_{t} \quad \varepsilon_{t} \sim N\left(0,1_{m}\right) \quad-\quad-
$$

Where: $y_{1}=o i l, g d p$, infl,intr, ipi \& exr and refers to $4 \mathrm{X} 1$ vector of endogenous variables; $A_{1}$ is the (m x m) matrix of contemporaneous effects; $A_{1}^{*}$ is the matrix (m x m) with lagged effects and $B$ represents the $(\mathrm{m} \times \mathrm{m})$ matrix of shocks referring to the "shortrun response" matrix. The next in line is the structural equation that links $\mu_{t}$ to $\varepsilon_{t}$ which takes account of the restriction. We can retrieve the reduced form residuals the SVAR model using;

$$
\mu_{t}=A^{-1} B \varepsilon_{t}
$$

$A^{-1}$ can be estimated to obtain the vector of structural shocks. $A^{-1} B \varepsilon_{t}$ is the response of $y_{1}$ to the structural shocks. Also, the variance-covariance matrix can be represented by

$$
\mu_{t}=A^{-1} B B^{T} A^{-T}
$$

Further adjustments to equation (15) will depend on the restrictions to be imposed (Lutkepohl 2006; Lutkepohl \& Kratzig 2004). The structure of restrictions in the model is defined as $(k-1)$. Hence the number of restrictions to be imposed can be shown:

$$
\frac{k(k-1)}{2}
$$

In this study, we handle the case of 6 variables SVAR which imposes the long-run C (1), matrix. The article by Kozluk \& Mehrotra (2009) specifies the SVAR modeling procedure for a six-variable case. Note that the 0 element in the matrix means there are no contemporaneous response expectation from specific shock in that element. But, the nonzero elements $a_{i l}(i=1,2,3,4,5,6 ; j=1,2,3,4,5,6)$ refer to the coefficients of the i'th element response to the shock of the jth element (Chen et al.,2016, p.45). The scheme in the matrix of equation (17) follows an order of relationship flowing from the exogenous to the endogenous variables. The SVAR restrictions in the matrix follow the constraints that flow from economic theory. Six restrictions are applied in tandem with economic theory.

According to the applicable cholesky triangular factorization, the Structural VAR estimates of short run pattern can be shown as follows: 
Oil Price Shocks and Macroeconomic Performance of the Nigerian Economy: A Structural VAR Approach 309

Estimate of Matrix A $\left[\begin{array}{c}\text { Variables } \\ \text { OILP } \\ \text { GDPR }_{t} \\ I N F L_{t} \\ I N T R_{t} \\ E X R_{t} \\ I P I_{t}\end{array}\right]\left[\begin{array}{cccccc}G D P R_{t} & O I L P_{t} & I N F L_{t} & I N T R_{t} & E X R_{t} & I P I_{t} \\ 1 & 0 & 0 & 0 & 0 & 0 \\ a_{21} & 1 & 0 & 0 & 0 & 0 \\ a_{31} & a_{32} & 1 & 0 & 0 & 0 \\ a_{41} & a_{42} & a_{43} & 1 & 0 & 0 \\ a_{51} & a_{52} & a_{53} & a_{54} & 1 & 0 \\ a_{61} & a_{62} & a_{63} & a_{64} & a_{65} & 1\end{array}\right]$
Estimate of Matrix B $\left[\begin{array}{c}\text { Variables } \\ \text { OILP } \\ \text { IDPR }_{t} \\ I N F L_{t} \\ I N T R_{t} \\ I P I_{t} \\ E X R_{t}\end{array}\right]\left[\begin{array}{cccccc}G D P R_{t} & O I L P_{t} & I N F L_{t} & I N T R_{t} & E X R_{t} & I P I_{t} \\ a_{11} & 0 & 0 & 0 & 0 & 0 \\ 0 & a_{22} & 0 & 0 & 0 & 0 \\ 0 & 0 & a_{33} & 0 & 0 & 0 \\ 0 & 0 & 0 & a_{44} & 0 & 0 \\ 0 & 0 & 0 & 0 & a_{55} & 0 \\ 0 & 0 & 0 & 0 & 0 & a_{66}\end{array}\right]$

One, oil price is exogenously determined and is not affected by a developing country and minimal producer like Nigeria (Amaiquema \& Amaiquema, 2017). Two, Economic growth does not respond simultaneously to any changes in the domestic variables in the equation (Kiliçarslan \& Dumrul, 2017). Three, inflation is mainly affected by changes in GDP and oil price. Four, interest rate is not simultaneously affected by exchange rate and industrial output. Finally, while industrial output may not directly be affected by only exchange rate, there are no restrictions on the effect on exchange rate by all the other variables (Basnet \& Upadhyaya, 2015).

\section{EMPIRICAL ANALYSIS AND RESULTS}

\subsection{Descriptive Statistics}

This sub-section of the study discusses the statistical properties of the variables that are used in the study. The features that are presented include the mean, median, standard deviation, kurtosis, Jarque-Bera and probability. The results are presented in table 2. The means of oil price, economic growth, inflation interest rate, industrial production index and exchange rate are $3.54,11.28,2.68,2.85,3.37$ and 3.52 respectively. Furthermore, the maximum values associated with the variables are 4.60, 14.17, 4.29, 3.45, 3.63 and 5.72 for oil price, economic growth, inflation interest rate, industrial production index and exchange rate. On the other hand, the minimum values associated with the variables are 2.67, 6.57, 1.68, 2.24, 2.89 and -0.39 for oil price, economic growth, inflation, interest rate, industrial production index and exchange rate respectively. The period of analysis for the variables covers from 1981 to 2018 making 38 observations for all the variables except for the GDP which has 37 observations because of the differencing factor. The variables with the highest variability (standard deviation) for the period are GDP and exchange rate with 2.37 and 1.89 respectively. The peak for the distribution which is measured by kurtosis shows that only interest rate with a value of 3.49 is above 3.0. 
Table 2 Descriptive Statistics

\begin{tabular}{lcccccc}
\hline & LOIL & LDGDP & LINFL & LINT & LIPI & LEXR \\
\hline Mean & 3.5435 & 11.2802 & 2.6762 & 2.8547 & 3.3660 & 3.5229 \\
Median & 3.3701 & 11.7992 & 2.5301 & 2.8670 & 3.3570 & 4.6220 \\
Maximum & 4.6019 & 14.1671 & 4.2882 & 3.4547 & 3.6299 & 5.7239 \\
Minimum & 2.6686 & 6.5658 & 1.6842 & 2.2443 & 2.8999 & -0.3953 \\
Std. Dev. & 0.6285 & 2.3695 & 0.7081 & 0.2783 & 0.1879 & 1.8923 \\
Skewness & 0.3638 & -0.6229 & 0.8704 & -0.6852 & -0.5023 & -0.8173 \\
Kurtosis & 1.7694 & 2.1344 & 2.7902 & 3.4951 & 2.4876 & 2.4294 \\
Jarque-Bera & 3.1511 & 3.5478 & 4.7399 & 3.2732 & 1.9607 & 4.6214 \\
Probability & 0.2069 & 0.1697 & 0.0935 & 0.1946 & 0.3752 & 0.0992 \\
Observations & 38 & 37 & 38 & 38 & 38 & 38 \\
\hline \multicolumn{7}{c}{ Author's Computation } \\
\hline
\end{tabular}

Since all other variables of the distribution have kurtosis value less than 3 , the distribution can be classified as platykurtic (short-tailed and fat). The probability values for the distribution are compared to the Jarque-Bera test of normality, to decide the asymptotic test. The table shows that the probability values are low for all the variables, the means are nearly equal to the medians, hence we conclude that the residuals for the distribution are normally distributed.

\subsection{Time Series Properties: Unit Root Test}

The unit root test for the study is conducted using the Augmented Dickey-Fuller (ADF) Approach.

The unit root test is performed on all the variables in the study (oil price, GDP, inflation, interest rate, industrial production index and exchange rate) and the results presented in Table 3. The values of the t-statistics became greater that the test critical values at $1 \%, 5 \%$ and $10 \%$ at first difference I (1). The probability values at first difference confirm the stationarity of all the variables at the level of integration. At the level of the joint stationarity test, the Fisher Chi-square value is 146.42 with probability of zero and the Choi Z-statistic value is -10.75 with probability of zero also. Therefore, the unit root test shows that all the variables are integrated at order of first difference [I(1)].

Table 3 Unit Root Test with ADF

\begin{tabular}{|c|c|c|c|c|c|}
\hline Method & & & Statistic & Prob. $^{*}$ & \\
\hline ADF - Fisher Chi-square & & & 146.421 & 0.0000 & \\
\hline ADF - Choi Z-stat & & & -10.7456 & 0.0000 & \\
\hline Series & t-stat & Prob. & Order of Integrtn & Max Lag & Obs \\
\hline L(OILP) & -5.8071 & 0.0000 & $\mathrm{I}(1)$ & 2 & 35 \\
\hline L(DGDP) & -8.3071 & 0.0000 & $\mathrm{I}(1)$ & 2 & 35 \\
\hline L(INFL) & -6.7757 & 0.0000 & $\mathrm{I}(1)$ & 2 & 35 \\
\hline L(INTR) & -5.9557 & 0.0000 & $\mathrm{I}(1)$ & 2 & 35 \\
\hline $\mathrm{L}(\mathrm{IPI})$ & -6.4684 & 0.0000 & $\mathrm{I}(1)$ & 2 & 35 \\
\hline $\mathrm{L}(\mathrm{EXR})$ & -5.1702 & 0.0001 & $\mathrm{I}(1)$ & 2 & 35 \\
\hline Test critical values: & $\begin{array}{c}1 \% \text { level } \\
5 \% \text { level } \\
10 \% \text { level }\end{array}$ & & $\begin{array}{r}-3.626784 \\
-2.945842 \\
-2.611531\end{array}$ & & \\
\hline
\end{tabular}

Source: Author's Computation 


\subsection{Optimal Lag Selection}

The optimal lag selection process is shown in Table 4. The lag that is selected to be used for our SVAR analysis as indicated by AIC and SC is lag four. Therefore, the lag to be used for our analysis of the SVAR is lag four.

Table 4 Optimal Lag Selection

\begin{tabular}{|c|c|c|c|c|c|c|}
\hline \multicolumn{7}{|c|}{$\begin{array}{l}\text { VAR Lag Order Selection Criteria } \\
\text { Endogenous variables: LOIL LDGDP LINFL LINT LIPI LEXR }\end{array}$} \\
\hline Lag & $\log \mathrm{L}$ & LR & FPE & AIC & $\mathrm{SC}$ & HQ \\
\hline 0 & -77.47337 & NA & $6.34 \mathrm{E}-06$ & 5.058992 & 5.331084 & 5.150543 \\
\hline 1 & 59.46202 & 215.777 & $1.45 \mathrm{E}-08$ & -1.058304 & 0.846342 & -0.417449 \\
\hline 2 & 119.6029 & 72.898 & 4.24E-09 & -2.521386 & 1.015814 & -1.331226 \\
\hline 3 & 177.6855 & 49.28226 & 2.23E-09 & -3.859729 & 1.310024 & -2.120265 \\
\hline 4 & 305.8503 & $62.1405^{*}$ & $5.21 \mathrm{e}-11^{*}$ & $-9.4455^{*}$ & $-2.6432^{*}$ & $-7.1567^{*}$ \\
\hline
\end{tabular}

${ }^{*}$ indicates order of lag selected based on criterion

LR: Modified LR test statistic (test at $5 \%$ level)

FPE: Final prediction error

AIC: Akaike information criterion

SC: Schwarz information criterion

HQ: Hannan-Quinn information criterion

Source: Author's Computation

\subsection{Structural VAR Estimates}

Table 5 shows the results of the structural VAR analysis in the study. The effect of oil price on the macroeconomic variables is shown in the first column of the table. The effect of oil price shock on the country's GDP and Industrial Production is negative and significant. On the other hand, the effect of oil price shock on inflation and interest rate is positive and significant. However, the effect of oil price shock on exchange rate is positive, but not significant. In other words, an increase in the price of crude oil in Nigeria elicits a decrease in GDP and industrial output. On the other hand, a decrease in the price of crude oil is accompanied by an increase in inflation, interest rate and exchange rate.

Table 5 Results of Structural VAR Test

\begin{tabular}{|c|c|c|c|c|c|c|}
\hline & OILP & GDP & INFL & INTR & IPI & EXR \\
\hline OILP & $\begin{array}{c}0.2561^{* * *} \\
(0.0000)\end{array}$ & & & & & \\
\hline GDP & $\begin{array}{l}-0.7567^{\text {**** }} \\
(0.0010)\end{array}$ & $\begin{array}{l}0.3406^{\text {*** }} \\
(0.0000)\end{array}$ & & & & \\
\hline INFL & $\begin{array}{l}0.8130^{* * *} \\
(0.0233)\end{array}$ & $\begin{array}{l}-0.5970^{* * * *} \\
(0.0093)\end{array}$ & $\begin{array}{l}0.4750^{* * * *} \\
(0.0000)\end{array}$ & & & \\
\hline INTR & $\begin{array}{c}0.0739 \\
(0.4126)\end{array}$ & $\begin{array}{c}0.0079 \\
(8936)\end{array}$ & $\begin{array}{c}0.0497 \\
(0.2105)\end{array}$ & $\begin{array}{l}0.1116^{* * * *} \\
(0.0000)\end{array}$ & & \\
\hline IPI & $\begin{array}{l}-0.1860^{\text {**** }} \\
(0.0000)\end{array}$ & $\begin{array}{l}-0.0858^{* * * *} \\
(0.0003)\end{array}$ & $\begin{array}{l}-0.0104 \\
(0.5198)\end{array}$ & $\begin{array}{l}-0.0679 \\
(0.3127)\end{array}$ & $\begin{array}{c}0.0444^{* * *} \\
(0.0000)\end{array}$ & \\
\hline EXR & $\begin{array}{c}0.2358 \\
(0.1302) \\
\end{array}$ & $\begin{array}{l}-0.2436^{\text {**** }} \\
(0.0065)\end{array}$ & $\begin{array}{l}0.2928^{* * *} \\
(0.0000)\end{array}$ & $\begin{array}{l}-0.6512^{* * *} \\
(0.0033)\end{array}$ & $\begin{array}{l}-0.2326 \\
(0.6718)\end{array}$ & $\begin{array}{c}0.1443^{* * *} \\
(0.0000)\end{array}$ \\
\hline
\end{tabular}




\subsection{SVAR Impulse Response}

This study applies the framework of impulse-response function to analyze and interpret the interaction between the variables of study in the short-run. The impulse-response function shows the responses of other variables like economic growth, inflation, interest rate, industrial production and exchange rate to one-time shock changes in oil price. This study performs the Cholesky decomposition on the SVAR Equation (17) and examines the responses of economic growth, inflation, interest rate, industrial output and official exchange rate to oil price shocks. Figure 1 shows the results of impulse-response functions for the responses of key macroeconomic variables to oil price shocks in Nigeria.

The first diagram in Figure 1 shows the response of oil prices to a shock from itself. The effect starts with a negative response and maintains it up to the $4^{\text {th }}$ period. The effect turns positive up to the $6^{\text {th }}$ period when it becomes negative. The negative trend is maintained until the $8^{\text {th }}$ period when it becomes damp. On the overall scale, the short run response of oil price to a shock by itself is negative.

The second diagram in Figure 1 shows the response of GDP (economic growth) to short term oil price shocks. The initial response of GDP to oil price shock is negative up to the $2^{\text {nd }}$ period when it turns positive. The upward trend is maintained up until the 5 th period. Thereafter, a negative trend emerges until the $8^{\text {th }}$ period when it becomes damp until the $10^{\text {th }}$ period. The overall short-run effect of oil price shock on GDP in Nigeria appears to be indeterminate.

The third diagram in Figure 1 illustrates the response of inflation to short term oil price shocks. The starting response of inflation to oil price shocks is positive and maintained up to the $5^{\text {th }}$ period. From the $5^{\text {th }}$ period to the $8^{\text {th }}$ period, the response is negative and becomes positive again to the $10^{\text {th }}$ period. The overall response of inflation to oil price shocks in Nigeria is positive.

The fourth diagram in Figure 1, shows the response of interest rate to oil price shocks in the short term. The initial response of interest rate is a mild negative up to the $4^{\text {th }}$ period. Thereafter, it turns mildly positive, gets to the 6th period and becomes negative again. From the $8^{\text {th }}$ period, it becomes positive till the $10^{\text {th }}$ period. The average effect of oil price shock on interest rate is mild, damp and can be largely regarded as indeterminate.

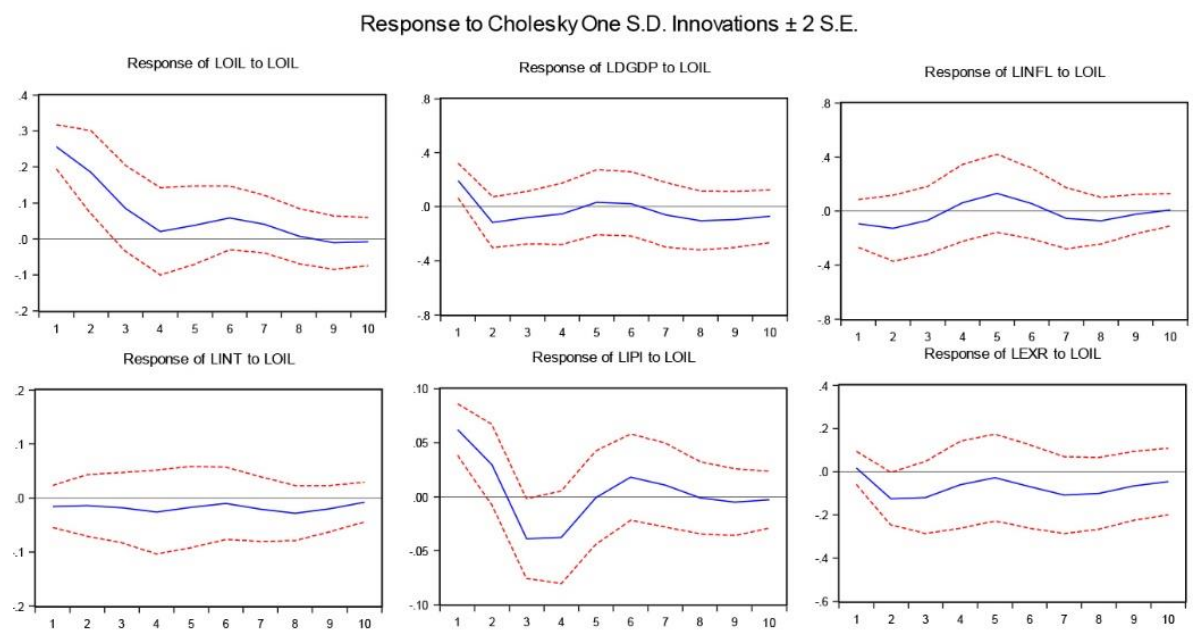

Fig. 1 Impulse-Response Function 
The fifth diagram in Figure 1 shows the response of industrial production to oil price shocks in the short term. The starting response of industrial output to oil price shock is a dramatic decline before it becomes flat between the $3^{\text {rd }}$ and $4^{\text {th }}$ periods. This is followed by a sharp increase up to the $6^{\text {th }}$ period. Thereafter, it declines mildly up until the $9^{\text {th }}$ period when it becomes damp till the end. The overall response of industrial output to oil price shocks is very dramatic and has both positives and negatives.

The sixth diagram in Figure 1 depicts the short term response of exchange rate to oil price shocks in Nigeria. The response of exchange rate starts with a sharp decline and flattens out between the $2^{\text {nd }}$ and $3^{\text {rd }}$ periods. This is followed with a positive which peaks in the $5^{\text {th }}$ period before becoming negative. The decline from the $5^{\text {th }}$ period flattens out between the $7^{\text {th }}$ and $8^{\text {th }}$ periods when it rises gently until the end.

\section{CONCLUSIONS}

This study examines the effect of oil price shocks on macroeconomic variables in Nigeria utilizing annual data over the period 1981 to 2018. Specifically, the study investigated the effect of oil price shocks on economic growth, inflation, interest rate, industrial production and exchange rate. Nigeria, as a small economy that is crude oil exporting and importer of finished oil products, makes the country an interesting case study. Several authors have written on the effect of oil price shocks on developing countries, but very few studies have focused on more than four variables with an expanded period to cover the recent times that witnessed the massive volatility in world oil prices. The study utilized the Structural VAR approach and specifically examined the long-run effect among the variables as well as the short-run impulse response function. The findings in the study suggest that oil price shocks have significantly and negatively affected economic growth and industrial output in Nigeria. This position is in tandem with studies like Bekhet \& Yusop (2009), Alley et al. (2014) and Kiliçarslan \& Dumrul (2017). However, the conclusion is at variance with Omojolaibi (2013), Igberaese, (2013), Yukata (2015) and Ifeanyi \& Ayenajeh (2016). The other set of results in the study shows that oil price shocks have significant positive effect on inflation. Also, while the effect is positive on interest rate and exchange rate, the result is not significant. The impulse response function shows that oil price shocks have negative effect on oil price changes. The results of impulse response function show a negative effect on output growth, while the effect on inflation is positive. While the effect of impulse response function of oil price shocks on industrial production shows large fluctuations, the effect on interest rate and exchange rate is minimal, largely mild and damp.

The findings in this study confirm that the response of the Nigerian economy to oil price shocks falls in tandem with the Renaissance theory of economic growth and the Dutch Disease theory of economic growth. First, the Renaissance theory is operational because an increase in oil price shock is not accompanied by economic growth. Second, the discovery and production of oil in Nigeria has led to the neglect of the other producing sectors of the economy over the years and stimulated the import of consumer goods. This is in line with the Dutch disease theory of economic growth. Nigeria's earnings from nonoil exports are less than $15 \%$ of total exports. It explains why the country runs into balance of payments problems any time the earnings from oil export drop. Also, Nigeria's industrial sector is heavily dependent on the external sector for raw material inputs. The heavy dependence of the economy on the external sector makes it very vulnerable to the shocks and volatility from the external sector. 
The results from this study like several others: (Omojolaibi, 2013; Khuram et al. 2015; Ifeanyi \& Ayenajeh, 2016) show that oil price shocks are a significant cause of macroeconomic fluctuation in oil-importing and exporting small and developing economies like Nigeria. Important macroeconomic variables like output growth, inflation, industrial production and exchange rate may be adversely affected by oil price volatility and shock. The diversification policy direction entails the conscious development of other important producing sectors of the economy like agriculture and industry. With the abundance of natural resources, the country can emphasize production and semi processing activities in the mines and mineral subsector of the economy. The government should encourage export-oriented operators with modern technological content and appropriate incentives in these sectors of the economy. This policy direction for the oil importing developing economy is to isolate the real sector from the vagaries of oil price volatility and diversify the export earning capability of the nation. Therefore, the policy recommendation would ensure that the government pursues the economic diversification that would reduce the nation's over-dependence on oil.

\section{REFERENCES}

Adeniyi, O., Omisakin, O., Yaqub, J., \& Oyinlola, A. (2012). Oil Price Exchange Rate Nexus in Nigeria: Further Evidence from an Oil Exporting Economy. International Journal of Humanities and Social Science, 2 (8), 113-121, DOI: 10.5296/ijafr.v9i1.14386.

Ahmed, H. J., \& Wadud, K. M. (2011). Role of oil price shocks on macroeconomic activities: An SVAR approach to the Malaysian economy and monetary responses. Energy Policy, 39 (2011), 8062- 8069, https://doi.org/10.1016/j.enpol.2011.09.067.

Alley I., Asekomeh A., Mobolaji H., \& Adeniran Y. (2014). Oil price shocks and Nigerian economic growth. European Scientific Journal, 10(9), 375-391.

Amaiquema, J. R. P., \& Amaiquema, A. R. P. (2017). Consequences of Oil and Food Price Shocks on the Ecuadorian Economy. Int'l Journal of Energy Economics and Policy, 7 (3), 146-151.

Ani, W., Ugwunta, D., Inyiama, O., \& Ike-Ekweremadu, N. (2014). Oil Price Volatility and Economic Development: Stylized Evidence in Nigeria. Journal of Economics and International Finance, 6 (6), 524538 DOI: $10.5897 / \mathrm{JEIF} 2014.0572$.

Awartani, B., Maghyereh, B., \& Ayton, J. (2019). Oil Price Changes and Industrial Output in the MENA Region: Nonlinearities and Asymmetries. Economic Research Forum, Working Paper No. 1342, https://doi.org/10.1016/j.energy.2020.117043.

Aydına, L., \& Acarb, M. (2011). Economic Impact of Oil Price Shocks on the Turkish Economy in the Coming Decades: A Dynamic CGE Analysis. Energy Policy, 39 (3), 1722-1731, https://doi.org/10.1016/j.enpol.2010.12.051.

Bala, U., \& Chin, L. (2018), Asymmetric impacts of oil price on inflation: An empirical study of African OPEC member countries. Energies, 11, 3017, DOI: 10.20944/preprints201808.0064.v1.

Basnet, H. C., \& Upadhyaya, K. P. (2015). Impact of oil price shocks on output, inflation and the real exchange rate: Evidence from selected ASEAN countries. Applied Economics, 47 (29), 3078-3091, DOI: 10.1080/00036846. 2015.1011322

Bekhet, H. A., \& Yusop, N. Y. M. (2009). Assessing the relationship between oil prices, energy consumption and macroeconomic performance in Malaysia: co-integration and vector error correction model (VECM) approach. Int'l. Bus. Research, 2 (3), 152-175.

Bermingham, C. (2008). Quantifying the impact of oil prices on Inflation. Central bank and financial services authority of Ireland research technical paper, 8/RT/08 November 2008.

Bhattacharya, K., \& Bhattacharya I. (2001). Impact of Increase in Oil Prices on Inflation and Output in India. Economic and Political Weekly, 36 (51), 4735-4741.

Bouri, E. (2019). The Effect of Jumps in the Crude Oil Market on the Sovereign Risks of Major Oil Exporters. Risks. 7 (4), 118. https://doi.org/10.3390/risks7040118

Bouri, E., Kachacha, I., \& Roubaud, D. (2020). Oil market conditions and sovereign risk in MENA oil exporters and importers. Energy Policy, 137, 111073. https://doi.org/10.1016/j.enpol.2019.111073

Bouri, E., Shahzad, S. J. H., Raza, N., \& Roubaud, D. (2018). Oil Volatility and Sovereign Risk of BRICS. Energy Economics, 70, 258-269. https://doi.org/10.1016/j.eneco.2017.12.018 
Chen, H., Liu, L., Wang, Y., \& Zhu, Y. (2016). Oil Price Shocks and U.S. dollar Exchange Rates. Energy, 112, 1036-1048. https://doi.org/10.1016/j.energy.2016.07.012

Coleman, S., Cuestas, J. C., \& Mourelle, E. (2010). A nonlinear analysis of the relationship between real exchange rates and real oil prices in African countries. CSAE Conference 2010 - Economic Development in Africa, 21st-23rd March. St Catherine's College, Oxford.

Corden, W., \& Neary, J. (1982). Booming Sector and De-Industrialisation in a Small Open Economy. Economic Journal, 92 (368), 825-848, https://doi.org/10.2307/2232670

Dawson, J. C. (2007). The effect of oil prices on exchange rates: a case study of the Dominican Republic. The Park Place Economist, 14 (1), (Article 10).

Hamilton, J. D. (1983). Oil and the macro-economy since world war II. Journal of Political Economy, 91 (2), 228-248. https://doi.org/10.1086/26114.

Hooker, M. A. (2001). What happened to the oil price macro-economy relationship?. Journal of Monetary Economics, 38, 195-213. https://doi.org/10.1016/S0304-3932(96) 01281-0.

Huang, Y., \& Guo, F. (2007). The Role of Oil Price Shocks on China's Real Exchange Rate. China Economic Review, 18 (4), 403-416, https://doi.org/10.1016/j.chieco.2006.02.003.

Ifeanyi O. N. \& Ayenajeh M. E. (2016). Impact of Crude Oil Price Volatility on Economic Growth in Nigeria (1980 2014). Journal of Business and Management, 18 (6) (I), 10-19.

Igberaese, T. (2013). The effect of oil dependency on Nigeria's economic growth. An unpublished M.Sc thesis from International Institute of Social Sciences, The Netherlands.

Iwayemi, A., \& Fowowe, B. (2011). Impact of oil price shock on selected macroeconomic variables in Nigeria. Energy Policy, 39, 603-612, DOI: 10.1016/j.enpol.2010.10.033.

Jawadi, F., Louhichi, W., Ameur, H. B., \& Cheffou, A.I. (2016). On oil-US Exchange rate Volatility Relationships: An Intraday Analysis. Economic Modelling, 59 (C), 329-334. https://doi.org/10.1016/j.econmod.2016.07.014.

Ji, Q., Shahzad, S. J. H., Bouri, E., \& Suleman, M. T. (2020). Dynamic Structural Impacts of Oil Shocks on Exchange Rates: Lessons to Learn. Journal of Economic Structures, 9 (20), 1-19, https://doi.org/10.1186/ s40008-020-00194-5.

Jiranyakul, K. (2016). Oil Price Shocks and Domestic Inflation in Thailand. MPRA Paper No. 62797, Available at: https://mpra.ub.uni-muenchen.de/71070/8/MPRA_paper_71070.pdf

Kiliçarslan, Z., \& Dumrul, Y. (2017). Macroeconomic Impacts of Oil Price Shocks: An Empirical Analysis based on the SVAR Models. Revista Economică, 69 (5), 55-72.

Kozluk, T., \& Mehrotra, A. (2009). The impact of Chinese Monetary Policy Shocks on South-east Asia. Economics of Transition, 17 (1), 121-145.

Laser, Y. (1987). Interest, Inflation, Growth and the Direction of the Hong-Kong Economy. Chinese Economic Reviews, 120 (8), 19-33

Lee, K. (1998). Oil Price Changes and Volatility; A Correlation Analysis on the Economy of China. Scholarly writers' publications, 15 (4), 44-49.

Lee, K., Ni, S., \& Ratti, R. (1995). Oil shocks and the Macroeconomy: The role of price variability. The Energy Journal, 16 (4), 39-56, https://www.jstor.org/stable/41322616

Lutkepohl, H. (2006). New Introduction to Multiple Time Series Analysis. New York: Springer Verlag.

Lutkepohl, H., \& Kratzig, M. (2004). Applied Time Series Econometrics. Cambridge: Cambridge University Press.

Mensah, L., Obi, P., \& Bokpin, G. (2017). Cointegration test of oil price and us dollar exchange rates for some oil dependent economies. Research in International Business and Finance, 42 (C), 304-311. https://doi.org/10.1016/j.ribaf.2017.07.141

Mork, K. A. (1989). Oil and the Macroeconomy when prices go up and down: An extension of Hamilton's results. Journal of Political Economy, 91, 740-744, https://www.jstor.org/stable/1830464.

Muhammad, J., \& Ghulam, S. K. (2017). Impact of Oil price Volatility and Macroeconomic Variables on Economic Growth of Pakistan. Review of Innovation and Competitiveness:A Journal of Economic and Social Research, 3 (1), 49-74. https://doi.org/10.32728/ric.2017.31/3

Mukhtarov, S., Mammadov, J., \& Ahmadov, F. (2019). The Impact of Oil Prices on Inflation: The Case of Azerbaijan. International Journal of Energy Economics and Policy, 9 (4), 97-102. https://doi.org/10.32479/ijeep.7712

Narayan, P. K., Narayan, S., \& Prasad, A. (2008). Understanding the oil price - exchange rate nexus for the Fiji islands. Energy Economics, 30 (5), 2686-2696.

Nazir, S., \& Hameed, T. (2015), Impact of Oil Price and Shocks on Economic Growth of Pakistan: Multivariate Analysis (Sectoral Oil Consumption). Business and Economics Journal, 6 (4), https://doi.org/10.4172/2151-6219.1000182

Ogundipe, O., Ojeaga, P., \& Ogundipe, A. (2014). Oil Price and Exchange Rate Volatility in Nigeria. Journal of Economics and Finance (IOSR), 5 (4), 01-09, DOI: 10.9790/5933-0540109

Okonkwo, I. V., \& Mojekwu, K. O. (2018). Crude Oil Price Fluctuations and Nigeria Economic Growth: $1997-$ 2015. International Journal of Research in Business, Economics and Management, 2 (2), 44-61, Available on: https://www.researchgate.net/publication/324971165 
Olomola, P. A., \& Adejumo, A. V. (2006). Oil Price Shock and Macroeconomic Activities in Nigeria. International Research Journal of Finance and Economics, 3, 28-34.

Omojolaibi, J. A. (2013). Does Volatility in Crude Oil Price Precipitate Macroeconomic Performance in Nigeria?. Int'l Journal of Energy Economics and Policy, 3 (2), 143-152.

Osuji, E. (2015). International Oil Prices and Exchange Rate in Nigeria: A Causality Analysis. International Journal of Academic Research in Economics and Management Sciences, 4 (3), 11-22. https://doi.org/10. 6007/IJAREMS/v4-i3/1798

Rotemberg, J. J., \& Woodford, M. (1996). Imperfect Competition and the effects of energy price Increases on Economic Activity. Journal of Money, Credit and Banking, 28, 549-577.

Sek, S. K., Teoa X. Q. \& Wong, Y. N. (2015). A Comparative Study on the Effects of Oil Price Changes on Inflation. Procedia Economics and Finance, 26, 630-636.

Shahzad, S. J. H., Bouri, E., Raza, N. et al. (2019). Asymmetric impacts of disaggregated oil price shocks on uncertainties and investor sentiment. Review of Quantitative Finance and Accounting, 52, 901-921. https://doi.org/10.1007/s11156-018-0730-9

Sibanda, K., \& Mlambo C. (2014). The Impact of Oil Prices on the Exchange Rate in South Africa. Journal of Economics, 5 (2), 193-199. https://doi.org/10.1080/09765239.2014.11884996

Tang, W., Wu, L., \& Zhang, Z. X. (2010). Oil Price Shocks and Their Short- and Long-term Effects on the Chinese Economy. Energy Economics, 32, 3-14.

Tiwari, A. K., Mutascu, M. I., \& Albulescu, C. T. (2013). The influence of the international oil prices on the real effective exchange rate in Romania in a wavelet transform framework. Energy Economics, 40, 714-733. https://doi.org/10.1016/j.eneco.2013.08.016

Udoka, C. O., \& Nkamare, S. E. (2014). The Implication of Crude Oil Glut on the Performance of The Nigeria Capital Market. Journal of Business Management, 18 (15), 11-23.

Volkov, N. I., \& Yuhn, K. (2016). Oil Price Shocks and Exchange Rate Movements. Global Finance Journal, 31, 8-30, DOI: 10.1016/j.gfj.2016.11.001

Yukata K. (2015). Oil prices and economic growth in developed countries. International Journal of Business and Social Sciences, 6 (11), 1-7.

\section{CENOVNI ŠOKOVI NAFTE I MAKROEKONOMSKE PERFORMANSE NIGERIJSKE EKONOMIJE: STRUKTURALNI VAR PRISTUP}

Ovaj rad proučava efekte cenovnih šokova nafte na makroekonomski performans Nigerijske privrede u periodu od 1980 do 2018. Uticaj cenovnih šokova nafte se proučava na makroekonomskim varijablama kao što su: rast proizvodnje, inflacija, kamata, devizni kurs $i$ indeks industrijske proizvodnje koristeći SVAR pristup (strukturna vektorska autoregresija). Rezultati istraživanja su pokazali da cenovni šokovi nafte značajno i negativno utiču na ekonomski razvoj i industrijsku proizvodnju. Dalje, iako rezulteti pokazuju da cenovni šokovi nafte imaju značajan pozitivni uticaj na inflaciju, njihov efekat je pozitivan i na kamatu i devizni kurs, ali ne značajno. Rezultati funkcije impulsnog odziva pokazuju negativan uticaj na rast proizvodnje, pozitivan na inflaciju ali umeren $i$ neodređen na industrijsku proizvodnju, kamatu i devizni kurs. Na osnovu nalaza ove studije, teorije "renesanse" $i$ "holandske bolesti" ekonomskog razvoja primenjive su na nigerisjku ekonomiju. Preporuke za donosioce odluka uključuju izdvajanje realnog sektora zemlje iz hirovitosti cene nafte $i$ potragu za ekonomskom diverzifikacijom da bi se smanjilo prekomerno oslanjanje na naftu.

Ključne reči: Cena nafte; Ekonomski rast; Inflacija; Devizni kurs; Industrijska proizvodnja; SVAR 